УДК 343.985

\title{
B. B. Tiщенко
}

\section{ШОДО ШЛЯХІВ ОПТИМІЗАЦІЇ РОЗРОБКИ МЕТОДИК РОЗСЛІДУВАННЯ ЗЛОЧИНІВ}

Нині активно розробблються криміналістичні методики розслідування різних рівнів і напрямів. Водночас теорія не встигає за запитами практики, а пропоновані методики не завжди задовольняють осіб, які ведуть розслідування. Тому виникає потреб́ в пошуку оптимальних моделей методик розслідування, побудованих з урахуванням сучасних теоретичних і методологічних положень криміналістичної науки.

На проблеми розробки вказаних моделей, розробки принципів формування криміналістичних методик в останні роки звертали увагу такі вчені, як І.О. Возгрін [1, с. 269-287], Ю.П. Гармаєв й О.Ф. Лубін [2], В.А. Журавель [3, с. 95-125], В.Є. Корноухов [4, с. 140-151], С.Ю. Косарєв [5, с. 238-240, 337-348], В.О. Образцов [6], М.В. Субботіна [7, с.15-17], В.В. Тішенко [8, с.115-125], С.Н. Чурилов [9, с. 49-66], А.В. Шмонін [10, с. 70-80], В.В. Шур [11, с. 216-235], М.П. Яблоков [12, с. 227-229].

Різноманітність ситуацій, із якими стикаються слідчі під час розслідування різних видів і масштабів злочинної діяльності, обумовлює постановку питання про можливість і доцільність створення загального методу розслідування або певної загальної, універсальної, базової моделі криміналістичної методики розслідування.

Так, С.Н. Чурилов пропонує створити вчення про загальний метод розслідування злочинів і включає в нього поняття про цей метод, його теоретичну модель, криміналістичну характеристику злочину цього виду, криміналістичну характеристику розслідування злочинів, принципи формування окремих криміналістичних методик і правила ї адапташіі до конкретного акту розслідування $[13$, с. 54-55]. Інакше кажучи, «поняття загального методу розслідування об' $€$ днує всі вже відомі поняття заключного розділу криміналістики», крім уяв.лення про поняття, історію розвитку криміналістичної методики, структуру цього розділу, завдання та значення, а також про систематизацію приватних методик розслідування та правила їх адаптації $[9$, с. 24]. 
B. B. Tiшекко. Шодо шляхів оптимізації розробки методик розслідування злочинів 91

Таким чином, пропоноване вчення про загальний метод розслідування включає фактично всі теоретичні положення криміналістичної методики, що не можуть належати тільки методу (нехай навіть загальному) розслідування злочинів. Вважаємо, метод стосовно діяльності з розслідування злочинів повинен вказувати на спосіб використання теоретичних знань із метою оптимізації цієї практичної діяльності. За своїм змістом вчення про загальний метод розслідування $\varepsilon$ нічим іншим, як методологінною частиною загальних положень криміналістичної методики. Тому можна погодитися з тим, що нічого кардинально нового й ефективного для теоріі та практики ця концепція не несе [14, с. 147].

Інша ідея пов'язана зі створенням базової (загальної) методики розслідування злочинів. Так, Ю.П. Гармаев та А.Ф. Лубін висловлюють таку гіпотезу: «Перш ніж формувати конкретні методики, повинна бути сформована загальна, універсальна модель, на базі якої тільки й можна створювати конкретні методики розслідування» [2, с. 79]. Така модель, на думку авторів, включає чотири етапи розслідування, відповідні їм завдання, а також рекомендовані для їх вирішення заходи й може використовуватися як шаблон під час розробки методик, а також для прикладного застосування в практиці розслідування. Вважаємо, що в такому випадку треба вести мову не про базову методику розслідування злочинів, а про формалізовану програму розслідування, яка наповнюється конкретним змістом шодо злочинів певної спрямованості. Проте запропоновані авторами чотири елементи базової методики не відображають повною мірою процес наукового дослідження слідчої діяльності.

Ідею про створення базової методики розслідування підтримує також В.А. Журавель, який пропонує розглядати таку методику у вигляді інформаційно-пізнавальної моделі. У ній учений видітяє два предметних рівня: ретроспективний і перспективний. Перший включає в себе криміналістичну характеристику злочинів певної категорії, у якій за статистичними показниками відображені кореляційні залежності між ї̈ елементами, що дозволяє відобразити типові варіанти розглянутої злочинної діяльності. Другий рівень описує типову модель розкриття злочину, що включає типові слідчі ситуашіі, програми розслідування, типові системи слідчих дій та оперативно-розшукових заходів. Крім того, дослідник виділяе також функціональний аспект базової моделі, який відображає взаємодію між елементами одного й різних рівнів (ретроспективного і перспективного), що дозволяє провести аналіз внутрішніх і зовнішніх каналів обміну інформацією.

у цілому можна погодитися з доцільністю побудови загальної інформаційно-пізнавальної моделі методики розслідування злочинів, хоча запропонована структура потребує уточнення й доповнення. Так, наприклад, ретроспективний рівень зазначеної моделі треба доповнити криміналістичною класифікацією злочинів, шо дозволить звернути увагу на особливості криміналістичних характеристик відповідних груп злочинів. Саме між цими елементами спостерігається рух інформації в межах ретроспективного рівня, а канал руху інформації «криміналістична характеристика - ти- 
пові слідчі версії характеризує обмін інформацією між ретроспективним і перспективним рівнями розглянутої моделі.

У літературі висловлюється думка також про те, шо базовою методикою варто називати систему наукових положень і розроблених на їх основі рекомендацій із розслідування декількох видів злочинів, об' $є$ днаних на основі загальних кримінально-правових і криміналістичних критеріїв [7, с. 4]. Вважаємо, що в цьому випадку бі.льш правильно говорити про комплексну, або міжвидову, методику розслідування злочинів, оскільки в них повинні відображатися особливості взасмозв'язку тих видів злочинів, які входять у цю злочинну діяльність, а також особливості змісту та взаємозв'язку стратегічних і тактичних завдань, що виникають у ході їх розслідування.

О.А. Крестовніков вбачає загальну концепцію розробки криміналістичної методики у виділенні ії загального завдання, яке полягає в адаптації технічного й тактичного інструментарію для вирішення типових криміналістичних завдань і програмуванні цілісної системи криміналістичної діяльності. Методологічну основу криміналістичної методики, на його думку, складають два розділи: 1) формування й опис типових інформаційних моделей злочинної діяльності; 2) утворення й використання моделей типових інформаційних моделей і програм криміналістичної діяльності [15, с. 248]. Крім того, він виокремлює такі принципи побудови окремих криміналістичних методик: а) типізація; б) оптимальний рівень загальності методики; в) системність; г) оптимальність рівня алгоритмізації [15, с. 249-252].

Треба зауважити, шо сформульоване О.А. Крестовніковим загальне завдання криміналістичної методики звужує ї̈ науковий інструментарій, не передбачає розробку й використання властивих саме їй засобів і методів, не характеризує специфіку завдань і змісту «криміналістичної діяльності». Досить абстрактно виглядають і принципи побудови окремих криміналістичних методик, шо зводяться до оптимальної класифікації останніх та оптимального рівня алгоритмізації розслідування. Звідси аморфною й позбавленої відповідної специфіки видається представлена автором структура криміналістичної методики розслідування: 1) організаційно-технічне, інформаційне, нормативно-правове забезпечення; 2) організація взаємодії учасників; 3) версійна та прогностична проробка вихідної ситуаціі; 4) планування, моделювання та програмування процесу дослідження; 5) виявлення, фіксація, декодування й систематизація криміналістичної інформаціï; 6) прийняття проміжних рішень і встановлення доказових фактів; 7) формування інтегральної інформаційної моделі об’єкта, що досліджується; 8) рішення кінцевого криміналістичного завдання [15, с. 252].

Вважаємо, що формування загальної (базової) моделі криміналістичних методик розслідування різних рівнів і видів повинно відбуватися не на основі якогось загального методу розслідування або універсальної, базової методики, а на основі спешіальних принципів, шо дозволяють врахувати системно-діяльнісний, функціонально-технологічний та евристичний характер розслідування з метою його оптимізації й вирішення поставлених перед ним завдань. 
B. B. Tiщекко. Щодо шляхів оптимізації розробки методик розслідування злочинів 93

До принципів формування криміналістичних методик, на нашу думку, варто вілнести такі вихідні положення:

1) розгляд і вивчення злочинної діяльності та слідчо-криміналістичної діяльності з позицій системно-діяльнісного й функціонально-технологічного піџходів;

2) використання положень і новітніх досягнень природничих, технічних і гуманітарних наук;

3) використання досвіду слідчої практики шляхом іï аналізу й узагальнення з наступною екстраполяцією в теорію й методологію розслідування;

4) розробка й систематизація методичних рекомендацій на основі криміналістичної класифікації злочинів і злочинної діяльності;

5) розробка методів пошуку доказової інформації на основі криміналістичного аналізу злочинів і створення іх інформаційно-пізнавальних моделей - криміналістичних характеристик відповідних груп, видів і підвидів злочинів;

6) визначення напряму розслідування з урахуванням особ́ливостей обставин, що підлягають встановленню щодо злочинів відповідного виду;

7) визначення стратегічних завдань розслідування з урахуванням особливостей його початкового й наступного етапів;

8) розробка методичних рекомендацій на основі виділення типових вихідних і наступних слідчих ситуацій та їх інформаційної оцінки;

9) розгляд типових тактичних завдань та окремих версій, шо постають із виділених слідчих ситуашій, а також використання технологічного підходу під час розробки програм іх вирішення й перевірки, які передбачають слідчі дії, оперативно-розшукові й організаційні заходи, використання спеціальних знань, тактичні операції, що здійснюються в певній послідовності, та умови їх проведення;

10) аналіз особливостей тактичних і технічних прийомів і засобів, що використовуються в ході проведення окремих слідчих дій і тактичних операцій.

Таким чином, перші п'ять принципів утворюють методологічні передумови, які зумовлюють науково обгрунтовану побудову базової моделі діяльності з розслідування злочинів. За допомогою таких принципів конструюється програмно-шільовий комплекс розумової та практичної діяльності щодо оптимальної організації й забезпечення розслі-дування.

Вважаємо, система названих принципів $\epsilon$ ключем до теоретичного формування методик розслідування окремих категорій злочинів. Ці принципи детермінують зміст і структуру окремих методик, а також слугують основою для успішної адаптаціі розроблених методик до розслідування конкретних злочинів або для побудови методики розслідування самим слідчим за відсутності відповідної науково розробленої методики.

Проб́леми формування методик розслідування пов'язані також із проблемою класифікації криміналістичних методик, якій було присвячено чимало досліджень.

Центральним рівнем криміналістичних методик зазвичай вважаються методики окремих видів злочинів. Виділяються також методики розсліду- 
вання більш вузької спрямованості: вбивств на замовлення, кишенькових крадіжок, розкрадань у будівельних організаціях тощо. Зазначені методики можна ше більше звузити, ввівши додаткові ознаки, наприклад: методика розслідування кишенькових крадіжок, вчинених у міському транспорті, або методика розслідування замовних убивств, вчинених щодо політичних діячів. Вважаємо, що в такому випадку краще говорити про методичні особливості розслідування певних різновидів базового виду злочинів в умовах відповідних типових слідчих ситуацій. Навряд чи можна погодитися з виділенням методик встановлення алібі, встановлення винної особи «за гарячими слідами», виявлення інсценувань. Щодо цього цілком слушно B.Є. Корноухов зауважує, шо мова повинна йти не про методики, а про окремі тактичні завдання [4, с. 148]. Крім того, незважаючи на деякі спільні риси, засоби й методи іх вирішення набувають спешифіки залежно від виду й характеру злочинів.

Часто, звертаючи увагу на актуальність методики розслідування тих чи інших злочинів (як правило, нових видів), дослідники відмовляються від ii розробки з причини недостатньої кількості емпіричного матеріалу або його відсутності. У літературі нерідко наголошується, що обов'язковим у побудові кожної методики $є$ вивчення й узагальнення достатнього масиву кримінальних справ із відповідного виду злочинів [14, с. 155]. Погоджуємося із зауваженням стосовного того, шо криміналісти не вправі сидіти й чекати, поки практика накопичить тисячі судових прецедентів, перш ніж перейти до ̈х узагальнення й формулювання рекомендацій [2, с. 53]. Керуючись запропонованими принципами формування окремих методик, доцільно розробляти орієнтуючі моделі таких «випереджуючих» методик із подальшим ї коригуванням і наповненням більш конкретним та емпірично обгрунтованим змістом. У такому разі треба використовувати методи прогнозування, екстраполяціі, аналогії, моделювання [16, с. 281-282]. Такі методики можуть називатися «Теоретичні основи методики розслідування...» відповідної категорії злочинів.

Заслуговує на увагу також питання про форму та зміст криміналістичних методик розслідування. У сучасних методиках розслідування все частіше з'являються програми розслідування, спрошується виклад пояснюючого матеріалу. Справа в тому, що велика кількість теоретичних положень, докладний виклад дискусійних поглядів i $\ddot{i x}$ критичний аналіз ускладнюють сприйняття практиком запропонованих методичних і тактичних рекомендацій, роблять методику з точки зору слідцого малоефективною для практичного використання. Проте чи означає це, шо теоретичні й методологічні положення у викладі окремих методик розслідування у всіх випађках повинні бути виключені? Це не так. Усе залежить віл того, на якому етапі формування знаходиться ця методика, наскільки теоретично й емпірично обгрунтована, наскі.льки аргументовані й апробовані викладені в ній рекомендаціі і, нарешті, кому вона адресована.

У дисертаційних і монографічних дослідженнях повинні знайти наукове обгрунтування погляди автора на принципи формування й побудови мето- 
дики, яка ним розроблюється з використанням усього арсеналу теоретичних знань, шо відносяться до об'єкта та предмета дослідження; повинні розглядатися дискусійні питання, аналізуватися й узагальнюватися практика, висловлюватися власні рекомендації шодо методики й тактики розслідування цієі категоріі злочинів. У підручниках і навчальних посібниках теоретичні положення викладаються в більш лаконічній формі й носять лише пояснювальний характер. У них обгрунтовуються запропоновані для успішного розслідування методи, прийоми й засоби, які вибудовуються в певну систему. У посібниках із розслідування злочинів доцільно особливу увагу приділити викладу програм дій слідчого, які будуються залежно від криміналістичної характеристики цієї групи злочинів і типових слідцих ситуашій. Р.С. Бєлкін вважає, що програми розслідування не повинні підміняти собою окремі методики, проте й не повинні вк.ючатися в їх зміст $[17$, с. 724$]$. Якшо з першою частиною цієї точки зору потрібно погодитися, то друга викликає заперечення. Вважаємо, теоретичне дослідження, присвячене розробці окремої методики розслідування, має включати в себе також прикладні (прагматичні) аспекти у вигляді рекомендованих програм і алгоритмів розслідування [18]. Тому можна погодитися з думкою В.А Журавля стосовно того, шо окремі криміналістичні методики можуть бути виражені в трьох формах: описова, формалізована та змішана [3, с. 125]. Головне тут - визначити основну функцію, призначення пропонованої методики та збалансувати в іi положеннях теоретичну, пояснювальну й прагматичну складові.

\section{Література}

1. Возгрин И.А. Введение в криминалистику / И.А. Возгрин. - СПб. : Ассоциация «Кридический центр», 2003. - ГЕлектронний ресурс). - Режнм доступу : http://lawdiss.org.ua/ books / a1780.doc.html.

2. Гармаев Ю.П. Проблемы создания крнмнналистических методик расследования преступлений. Теория и практика / Ю.П. Гармаев, А.Ф. Лубин ; Ассоциация «Кридический центр». - СПб. : Ю)ридический центр Пресс, 2006. - 303 с.

3. Журавель В.А. Криміналістичні методики: сучасні наукові концепції : [монографія] / В.А. Журавель. - Х. : Вид. агенція «Апостіль», 2012. - 304 с.

4. Корноухов B.E. Методика рассиедовання преступлений: теоретическне основы / B.E. Kорноухов. - M. : Норма, 2008. $-213 \mathrm{c}$.

5. Косарев С.Ю. История и теория криминалистической методики расследования преступлений / С.К). Косарев. - СПб. : Ю)ридический центр Пресс, 2008. - 351 с.

6. Образцов В.А. Криминалистика: модели средств и технологий раскрытия преступленнй / В.А. Образцов. - М. : Изд-во ИМПЭ-ПАБЛИШ, 2004. - 400 с.

7. Субботина М.В. Базовая методика расследования преступ.ений: суть и значенне / М.В. Субботина // Вестник криминалистики. - М., 2007. - Выл. 1(21). - С. 15-17 ; Субботина M.В. Структура базовой методики расследования преступлений / M.В. Субботина // Вестник криминалистики. - М., 2006. - Вып. 2(18). - С. 4-7.

8. Тіщенко В.В. Тесретичні і практичні основи методики розслідування злочинів : Гмонографiяl / B.В. Тіщенко. - О. : Фенікс, 2007. - 216 c.

9. Чурилов С.Н. Криминалистическая методика расследования: проблемы, тенденции, перспективы / С.Н. Чурилов. - М.: Кстицинформ, 2011. - $128 \mathrm{c}$.

10. Шмонин А.В. Методология криминалистической методики / А.В. Шмонин. - М. : Юристь, $2010 .-480 \mathrm{c}$. 
11. Шур Б.В. Теоретичні основи формування та застосування криміналістичних методик / Б.В. Шур. - Х. : Харків юридичний, 2010. - 320 с.

12. Яб̆локов Н.П. О некоторых проблемах разработки кримнналистической методики преступле. ний / Н.П. Яблоков // Вестнитк криминалистики. - М., 2005. - Вып. 3(15). - С. 12-24.

13. Чурилов С.Н. Методика расследования преступлений. Общие положения / С.Н. Чурилов. - М. : Юстицинформ, 2009. - 145 с.

14. Яблоков Н.П. Криминалистика: природа и система / Н.П. Ябллоков, Ф.Ю. Головнн. - М. : Норма, 2005. - $288 \mathrm{c}$.

15. Крестовников О.А. Снстемно-деятельностный аналнз методологин крнминалистики : Iмонография」/ О.А. Крестовников. - М. : К)рлитиннформ, 2013. - 272 с.

16. Журавель В.А. Трансформации криминалистической методики в современных условиях / В.А. Журавель // Криміналістика та судова експертиза: наука, навчання, практика : зб. наук. пр. : у 2 т. / уклад. : Г.С. Малєвскі, В.С. Шепітько. - Х. : Апостіль, 2014. - Т. 1. - C. $273-284$

17. Белтин Р.С. Курс криминалистики / Р.С.Белкин. - М.: К)рист, 2001. - 784 С.

18. Ищенко Е.П. Алгоритмизация стедственной деятельности / Е.П. Ишенко. Н.Б. Водянова. - М. : Юрлитинформ, 2010. - 304 с.

\section{Анотація}

Tiщенко B. B. Щодо шляхів оптимізації розробки методик розслідування злочинів. - Стаття.

У статі аналізуються сучасні підходи до формування криміналістичних методик розслідування злочинів. Розглядаються спірні питання створення загального методу розслідування й базової криміналістичної методики. Внсловлюсться думка про можливість і доцільність утворення загальної базової моделі крнміналістичної методики на основі запропонованих принципів побудови останньоі. Розглянуто деякі дискусійні питання класифікації, умов розробки й функцій криміналістичної методики розслідування.

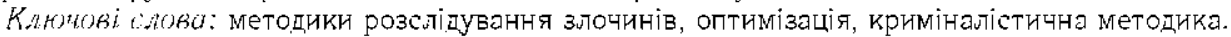

\section{А н н о т а и я}

Tuщенко B. B. О путях оптимизации разработки методик расследования преступлений. - Статья.

В статье анализируются современные подходы к формированию криминалистических методик расследования преступлений. Рассматриваются спорные вопросы создания общего метода расследования и базовой криминалистической методики. Высказывается мнение о возможности и целесообразности создания базовой модели криминалистической метолики на основе предложенных принципов построения последней. Рассмотрены некоторые дискуссионные вопросы классификации, условий разработки и функций криминалистической методики расследования.

Kлюtевые слова: методики расследования преступлений, оптимизация, криминалисти. ческая методика.

\section{S u $\mathrm{m}$ in a r $\mathrm{y}$}

Tishchenko V. V. As for ways to optimize the development of methods of investigating crimes. - Article.

The article examines current approaches to the formation of forensic techniques crime investigation. We consider the controversial issue of establishing a general method and basic forensic investigation techniques. It has been suggested the possibility and feasibility of the formation of general basic model of forensic techniques based on the proposed construction principles of the latter. We consider some discussion the classification, terms of development and functions of lorensic investigation techniques.

Key words: crime investigation techriques, optimization, forensic technique. 